\title{
Rendészeti vezetés dinamikusan változó környezetben
}

\section{BERTALAN Dávid ${ }^{10}$}

\begin{abstract}
A tanulmány központi témája, hogyan változott a biztonsági környezet az elmúlt 20 évben, a 2001. szeptember 11-ei New York-i terrortámadást követően. Továbbá tárgyalja, hogy melyek azok a jelenségek, fenyegetések, amelyek formálták mind a hazai, mind a nemzetközi biztonsági környezetet, valamint, hogy hogyan vált egyre kiszámíthatatlanabbá, bizonytalanabbá világunk, hogyan alakult ki a dinamikusan változó környezet. Bemutatom a rendészeti és honvédelmi hivatásrendek közeledésének jelenségét. A tanulmány második részében egyes rendészeti szervezetek számára alkalmazható elméleteket, újfajta vezetéselméleti módszereket és azokhoz kapcsolódó alapelveket ismertetek, amelyek segíthetnek a dinamikusan változó viszonyok közötti szervezetvezetésben.
\end{abstract}

Kulcsszavak: dinamikusan változó környezet, VUCA, rendészeti vezetés, hivatásrendek közeledése, küldetésorientált vezetés.

\section{Bevezetés}

A tanulmány vizsgálja, hogy miként változott meg a biztonsági környezet, mind hazai, mind nemzetközi vonatkozásban, valamint, hogy melyek voltak azok a jelenségek, fenyegetések, amelyek leginkább formálták a biztonsági környezetet és alakították az azokra adott válaszlépések módszertanát. Álláspontom szerint, a rendészeti és honvédelmi hivatásrend feladatait, eljárási rendjeit tekintve folyamatosan közeledett és jelenleg is közeledik egymáshoz, amelynek egyik oka az ismertetett fenyegetések, események hatása. Az így kialakuló, úgynevezett dinamikusan változó környezetben a tradicionális vezetési módszerek nem feltétlenül érik el a kívánt eredményességet, azonban a katonai területen, valamint a civil szférában is alakultak ki olyan elméletek, amelyek alkalmazhatók egyes rendészeti szervezetek feladatellátása során.

Jelenleg a Nemzeti Közszolgálati Egyetem Hadtudományi Doktori Iskolájának doktorandusz hallgatója vagyok. Kutatási témám a 21. század múveleti környezete, a humán környezet és a katonai erő kapcsolata müveletek során, azon belül a közös döntéshozatal és a vezetés-irányítási rendszerek kialakításának lehetőségei, illetve szükségszerüsége a hon- és rendvédelmi együttműködés során.

Bertalan Dávid ogy. alezredes, Nemzeti Közszolgálati Egyetem Hadtudományi Doktori Iskola, doktori hallgató.

Dávid Bertalan, University of Public Service, Doctoral School of Military Sciences, PhD student. E-mail: vido288@ gmail.com 


\section{Hogyan változott a biztonsági környezet az elmúlt 20 évben?}

A Világkereskedelemi Központ ikertornyai ellen 2001. szeptember 11-én intézett New York-i terrortámadást követően a hadviselés elveiben és módszertanában gyökeres változások történtek, új elemek jelentek meg. Az afganisztáni, majd később az iraki intervenciók szintén jelentős változásokat indukáltak a hon- és rendvédelmi szervezetek, illetve a nemzetbiztonsági szolgálatok feladatrendszerében. A hadviselés elméletében az 1980-as évek vége óta létező és egyre nagyobb teret nyerő generációs elméletek, azon belül is az úgynevezett negyedik generációs hadviselés - amely az aszimmetrikus hadviseléssel azonos fogalmat takar - előtérbe kerültek a 21. század első évtizedében, hiszen az Amerikai Egyesült Államok és szövetségeseinek hadereje mindkét hadszíntéren aszimmetrikus hadviselést folytató ellenséggel találta szemben magát. Elmondható, hogy az elmúlt két évtizedben a biztonsági környezet - amelyben mind a rendészeti, mind a honvédelmi hivatásrend tevékenykedik - jelentős változásokon ment át, komplexszé, valamint a felhalmozott átláthatatlan mennyiségű ismeretanyagnak köszönhetően egyre kiszámíthatatlanabbá vált. A tanulmányban bemutatom, hogy mit is jelent az, hogy a biztonsági (múveleti) környezet komplex, kiszámíthatatlan, dinamikusan változó, illetve, hogy annak milyen hatása van, ha van egyáltalán, a rendészeti vezetői tevékenységre, valamint a rendészeti szervezetekre.

Mindenekelőtt meg kell vizsgálnunk, hogy egy adott probléma mitől válik bonyolulttá, illetve komplexszé, esetleg kaotikussá. Elmondható, hogy a bonyolult problémák különböznek a komplex problémáktól. Az előbbit, habár nagy erőfeszítést és energiaráfordítást igényel, de alapvetően megoldható kihívásoknak tekintjük, amelyek megfelelnek az előrejelzéseknek, előzetes várakozásoknak. A bonyolult dolgok, folyamatok egyszerű lépésekre bonthatók. A komplexszé vált problémákat azonban, szinte bármekkora erőforrásokat is fordítunk rájuk, nem vagyunk képesek nyomon követni, és mérlegelni azok helyes megoldását, valamint nem írhatók le több egyszerű dolog együtteseként, továbbá a végtelen/nagy számú változó, befolyásoló tényező nem felmérhető, így hasonló esetek is eltérő végkifejlettel járhatnak. Az elmúlt évtizedekben a technológiai fejlődésnek köszönhetően a világban megnövekedett az interdependencia, az események, személyek, folyamatok egymástól való kölcsönös függősége, és habár a monitoring- és döntési rendszerek területén is jelentős előrelépés történt, ezek nem bírták lekövetni a komplexszé vált problémákat. Ennek következtében a világ jóval gyorsabbá és kiszámíthatatlanabbá vált. ${ }^{2}$

Ezek alapján a szakirodalom a biztonsági környezetet négy típusba sorolja: egyszerű, bonyolult (komplikált), komplex (dinamikusan változó) és kaotikus. Az első

\footnotetext{
Jó példa erre a 2011-ben lezajlott arab tavasz. Az egész eseménysorozat Tunéziából indult el, ahol egy gyümölcsárus felgyújtotta saját magát, protestálásképpen az elnyomó rendszer ellen. Ezt követően a közösségi médiának, a videómegosztó portáloknak és az internetnek köszönhetően a készült képsorok órák alatt bejárták az arab világot, és kiszámíthatatlan, addig elképzelhetetlennek tűnő történéseket indukáltak. Az ilyen komplex folyamatok, események hagyományos megoldásokkal kezelhetetlenek. Stanley McChrystal: Csapatok csapata - Szervezeti együttmúködés és elköteleződés felsőfokon. Budapest, HVG, 2016. 74-75.
} 
két esetben kiszámítható, míg a második kettővel kapcsolatban kiszámíthatatlan környezetről beszélhetünk. Egyszerú a biztonsági környezet, ha van egy olyan megoldás a felmerülő problémákra, amely könnyen azonosítható, és az összes opció közül egyértelmúen eldönthető, hogy az a legjobb. A probléma megoldása mindenki számára megismerhető, rutinszerű működést jelent, ahol kevés az adminisztráció. A komplikált környezetben a problémák megoldásai bár több lépésből állnak, azok azonosítása időigényes, azonban nem lehetetlen. Az egyes részelemek között fennálló kapcsolatok felismerhetők, a bonyolult folyamatok egyszerű lépésekre bonthatók, amelyek így megoldhatóvá válnak. A legtöbb gazdasági szervezet - főleg amely több évtizedes múltra tekint vissza -, valamint a rendészeti szervek is ilyen környezetre optimalizált szervezetek. A komplex vagy más néven dinamikusan változó környezetben az elemzéseken alapuló, bonyolult környezetre optimalizált döntéshozatali, vezetési megközelítések már nem múködnek. Az ilyen környezetben az egyes jelenségek között már sok kapcsolat van, amelyek nehezen azonosíthatók, azokból megfelelő következtetést nehézkesen lehet levonni. A kiszámíthatatlanság jelentősen megnövekszik, az ilyen környezetben dolgozó vezető nem láthatja mindig a megfelelő megoldást (könnyen lehet, hogy nincs is egy megfelelő megoldás). Sokszor kevés, nem teljes körű információból kell idő előtt meghozni a döntéseket. A szervezetek tekintetében felértékelődik a szervezeti adaptációs képesség, amelynek segítségével gyorsan lehet alkalmazkodni a változó biztonsági környezethez. A kaotikus környezetben legtöbbször még magát a problémát sem ismerjük pontosan. A legjobb példa erre a 2019-ben Kínából indult és még jelenleg is zajló Covid-19-világjárvány. $\mathrm{Az}$ ilyen esetekben a rendelkezésre álló információ igen csekély, nincsenek cselekvési mintázatok. A vezetők számára előtérbe kerül az intuíció, amelynek segítségével döntéseket lehet hozni. ${ }^{3}$

A dinamikusan változó környezetet másnéven VUCA-környezetnek is nevezik, amely egy angol mozaikszó: volatile - gyorsan változó, uncertain - bizonytalan, complex - komplex, összetett, ambiguous - többértelmü. ${ }^{4} \mathrm{~A}$ katonai terminológiában és az angolszász katonai felső vezetés képzésében már az 1980-as évek közepétől alkalmazzák ezt a kifejezést a dinamikusan változó környezet megnevezésére. Nem véletlenül, ugyanis elsőként a katonák, közülük is főleg a különleges múveleti feladatokat ellátók voltak azok, akik szemben találták magukat olyan múveleti környezettel, amely kiszámíthatatlan, bizonytalan volt, azonban a vezetőknek mégis döntéseket kellett hozni, és elvégezni a rájuk bízott feladatokat. Az iraki és afganisztáni megszállás során tapasztaltak csak erősítették az addig kialakított elméleteket, és rávilágítottak arra, hogy a hagyományos vezetési elvek, elméletek nem múködnek hatékonyan egy olyan dinamikusan változó környezetben, mint egy 21. századi, aszimmetrikus hadviselést folytató ellenséggel szemben vívott háború.

Porkoláb Imre: A stratégia múvészete - Szervezeti innováció kiszámíthatatlan környezetben - Szun-Ce gondolatai alapján. Budapest, HVG, 2019b. 29-31.

4 McChrystal (2016): i. m. 80. 
A VUCA-környezet legfontosabb jellemzői a kiszámíthatatlanság és a bizonytalanág. Amikor ilyen környezetben kell feladatot végrehajtani, az információ mennyisége folyamatosan növekszik, köszönhetően az elmúlt évtizedekben végbement, az információtechnológia területén jelentkező robbanásszerű fejlődésnek. A döntések meghozatalára rendelkezésre álló idő viszont folyamatosan csökken.

A legtöbb szervezet, köztük a rendészeti szervek is bonyolult biztonsági környezetre fejlődtek ki. Azonban a társadalmakban jelentkező jelenkori kihívások sokkal inkább komplex, VUCA-környezetet teremtenek. A régi szervezeti struktúrák, amelyekben a hagyományos vezetési stílusok, módszerek honosodtak meg, nem képesek hatékonyan kezelni ezeket a kihívásokat. Ez a privát szektor multinacionális „megavállalataira” ugyanúgy érvényes, mint a rendészeti szervekre. A magánszektorban is megjelentek olyan szereplők az elmúlt 10-15 évben, amelyek ezekre a helyzetekre specializálódtak, ezek a startupvállalkozások. Az ilyen jellegú cégek felépítése és vezetése hasonló az irreguláris hadviselést folytató (gerillák, terrorszervezetek), hálózatosan szerveződő szervezetek decentralizált felépítéséhez. A döntéshozatali folyamat sokkal gyorsabban megy végbe, akár még nem elegendő mennyiségú információ rendelkezésre állása esetén is. Ezáltal egy startup gyorsabban tud reagálni a dinamikusan változó környezetre, amely javítja a versenypozícióit a lassúbb, nehezebben reagáló nagyvállalatokhoz képest.

Az ilyen komplex, kiszámíthatatlan kihívások komoly problémákat okozhatnak az egyszerúbb korokban létrejött, hagyományos szervezeteknek. Ennek okán válik kiemelkedően fontossá a szervezeti adaptáció, a szervezeti kultúra megváltoztatása, az új tanulási képességek elsajátítása, a rugalmasság. Különösen igaz ez a rendészeti szervezetek vonatkozásában, ahol a meglévő hagyományos, törvény által nevesített feladatok mellett (például közrendvédelmi, közlekedésrendészeti, hagyományos bűnügyi, bűnfelderítési feladatok) merőben új kihívásokkal kell szembenézni.

A jelenlegi biztonsági környezetben a rendészeti szerveket is érintő új kihívások, kockázatok és fenyegetések is ilyen komplex problémák, amelyek megoldása a hagyományos, tervezésre és redukcionista ${ }^{5}$ vezetésre alapozó módszerekkel nem, vagy csak nagyon nehézkesen oldhatók meg. ${ }^{6}$ Véleményem szerint az alábbi jelenségek azok, amelyek rávilágítanak arra, hogy a biztonsági környezet dinamikusan változó, és azok megoldása a hagyományos vezetési módszerekkel nem megoldható, csakúgy, mint a katonai erők vezetése szempontjából sem.

$\mathrm{Az}$ erősödő nemzetközi terrorizmus az eddigiektől eltérő, új típusú kihívások elé állította a plurális demokráciára épülő (nyugati) társadalmakat, azok rendészeti és nemzetbiztonsági szervezeteit. A későbbiekben a 2010-es évek elejétől, közepétől az önmagát Iszlám Államnak nevezett terrorszervezet tevékenységei az általa

\footnotetext{
A vezető külön-külön feladatokra osztja szét a folyamatban lévő mủveleteket, és azokat a saját kezében fogja össze. A beosztottaknak nincs szükségük rá, hogy megismerjék egymást, illetve az egyéb munkafolyamatokat, elég, ha a saját vezetőjükre hallgatnak.

6 McChrystal (2016): i. m. 100.
} 
fémjelzett új típusú terrorizmus felhasználásával jellemzően az európai országok állampolgárai számára is „testközelbe” hozták az aszimmetrikus hadviselést.

Ezt követően a 2014-ben kirobbant ukrán válság, a Krím annexiója, valamint az azóta is tartó kelet-ukrajnai konfliktus a hibrid hadviselést helyezték a tudományos érdeklődés középpontjába. A reguláris, irreguláris és információs hadviselés puha, közepes és kemény módszereinek rugalmas, magas szinten koordinált alkalmazása a valós és virtuális múveleti térben merőben új minőséget (szintet) képvisel a történelemben, amely nemcsak a klasszikus haderő alkalmazását befolyásolja, hanem változásokat indukál a társadalom humán környezetében is, ami új kihívások elé állítja a rendészeti erők és a nemzetbiztonsági szolgálatok múködését, múködtetését, munkatársainak felkészültségét és kiképzését is. A hibrid hadviselés fenyegetése és kockázatai vizsgálatának rendészeti és nemzetbiztonsági szempontú megközelítése azért is indokolt, mert e jelenség egyik domináns jellemzője, hogy a kikényszerített konfliktust lehetőség szerint a háborús küszöb alatt tartsa, azonban az erőszakos érdekérvényesítő cselekmények jelentős része már a megtámadott ország területén, illetve a kapcsolódó kibertérben zajlik.

A szervezett bűnözés és a nemzetközi kábítószer-kereskedelem egyes országokban - mint például Mexikó - akkora méreteket öltött, hogy pusztán rendészeti eszközökkel már nem lehet megfékezni a kialakult válságot. Úgy gondolom, hogy a narkoterrorizmus szintén egy olyan jelenség, amelynek kezelése kapcsán a katonai, rendészeti, titkosszolgálati munka szoros együttmüködésben kell, hogy megvalósuljon.

A 2015-ben a közel-keleti válság sújtotta területekről elindult illegális menekülthullám további nehézségek elé állította az európai országokat. A menekültválság még ma is központi téma a biztonságpolitikával foglalkozó kutatásokban, az egyes érintett államok különböző stratégiákat alkalmaztak annak kezelése kapcsán, ami egyrészt alapul szolgált a további vitákra, másrészt az ebből adódó inkoherencia és annak szinergiái eltérő terheket róttak az érintett országokra. A menekültválság rendszerszintű, illetve az illegális menekültek személyi, humanitárius kezelése szintén összkormányzati megközelítést igényel, amelyben a különböző hivatásrendek hatékony együttműködése kritikus jelentőségű.

A biztonsági környezetben bekövetkezett változásokat már többen felismerték, amely változások mind a tudományos közösségben, mind a jogalkotásban is megjelennek. Példaként említhető Magyarország Nemzeti Biztonsági Stratégiája, ${ }^{7}$ amelyben a jogalkotó nevesíti is a biztonsági környezet változásának kiszámíthatatlan jellegét és az abból fakadó nehézségeket:

„44. Magyarország biztonsági helyzete jelenleg szilárd, NATO és EU tagsága pedig ezt a biztonságot tovább növeli. A kihívások változó jellege és a biztonsági környezet egyes tendenciái fokozatos romlást vetítenek előre, amelynek fő elemei: a váratlanság,

1163/2020. (IV. 21.) Korm. határozat Magyarország Nemzeti Biztonsági Stratégiájáról. 
a változékonyság, az összetettség, a hatalmi centrumok közötti növekvő versengés, a globális közjavak újraosztásának szándéka, a klímaváltozás, a szúkebb régiónk geostratégiai kihívásai, a befagyott konfliktusok, a nemzetközi jog csökkenő kikényszeríthetősége, a migráció kiváltó okai és következményei, a túlnépesedés, az erőforrások szúkössége, a fundamentalista vallási irányzatok és a terrorizmus, a válságok átalakuló jellege, a technológiai forradalom és a növekvő digitális és pénzügyi sérülékenység." ${ }^{8}$

A biztonsági környezet változásának hatásai, véleményem szerint megfigyelhetők a rendészeti, illetve a honvédelmi hivatásrend közeledésében is. Az elmúlt két évtizedben a nemzetközi terrorizmus, a hibrid hadviselés, egyes országokban (főleg Dél- és Közép-Amerikában) a narkoterrorizmus, az ellenőrizetlen és nagyszámú Közel-Keletről Európába irányuló migráció egyre inkább közelebb hozta egymáshoz a hivatásrendeket. A katonák által múveleti területen alkalmazott eljárások, eszközök megjelentek a rendészeti munka során is. Különös tekintettel igaz ez a különleges múveleti feladatokat, illetve a rendészeti keretek között a terrorelhárítási, rendőri bevetési feladatokat ellátó egységekre. A katonai alakulatok által az iraki, illetve az afganisztáni hadszíntéren szerzett tapasztalatok megváltoztatták az általuk alkalmazott eljárásokat, amely indukálta a felszerelésben, illetve eszközökben bekövetkezett változásokat. Ezek az eszközök, illetve eljárások átkerültek a rendészeti területre, figyelembe véve a tényt, hogy a rendvédelmi szervek más jogi környezetben, más erőalkalmazási lehetőségekkel rendelkeznek, mint a katonai egységek. Azonban elmondható, hogy a változtatásra való igény mindkét (katonai, rendőri) oldalról jelentkezett. Egyrészt az európai kontinensen is egyre több terrortámadást követtek el (például 2015 - Párizs ${ }^{9}$ ), ahol a rendészeti szervek felkészült, katonai taktikát alkalmazó terroristákkal kerültek szembe. A katonák pedig olyan feladatokat hajtottak végre, amely alapvetően a rendészeti szervek hatáskörébe tartozik. Példaként említhetnénk, hogy a 2015-ös menekültválság óta Magyarország déli határszakaszán egyes katonai alakulatok a rendőri szervekkel együtt hajtják végre a határvédelmi feladatokat. Továbbá gondolhatunk akár a 2020-as évben a Sars-CoV-2 vírus által kirobbant Covid-19-világjárvány miatt hazánkban is bevezetett különleges jogrendi állapotra (Veszélyhelyzet), ${ }^{10}$ amelynek során a rendőri és katonai egységek közösen teljesítenek járőrszolgálatot Magyarország területén. A komplex válságok komplex reagálást igényelnek, amelyeknek jellegükből fakadóan nagyon sok szereplője van, akik tevékenységének összehangolása (szinkronizálása, koordinálása) a sikeres reagálás egyik feltétele. Az együttmúködés fontosságát jelzi e gondolat a komplex fenyegetések során. ${ }^{11}$ Azonban felmerül a kérdés, hogy a hivatásrendek ilyenfajta közeledése pozitívan vagy esetleg negatívan hat a feladatellátásra, a szervezetekre. Jómagam úgy gondolom, hogy ez a változás szükségszerū,

\footnotetext{
1163/2020. (IV. 21.) Korm. határozat Magyarország Nemzeti Biztonsági Stratégiájáról 44. pont.

Trautmann Balázs: Európa veszélyben? honvedelem.hu, 2015. 12. 15.

Országgyülés Hivatala: A különleges jogrend és a veszélyhelyzet. Infojegyzet, (2020), 6. 1-4.

Boldizsár Gábor: Paratroopers in future operations. Security and Defence Quarterly, 3. (2014), 2. 47.
} 
hiszen a megváltozott biztonsági környezet, a megszerzett tapasztalatok indukálták ezeket a változásokat. El kell fogadnunk, hogy ez a realitás, ilyen környezetben kell a rendészeti szerveknek végrehajtaniuk a törvény által rájuk szabott feladataikat, azonban nem szabad szem elől tévesztenünk a rendészeti szervek szolgáltató funkcióit sem, amely területek „militarizálódása” nem kívánatos.

\section{Új megközelítés a rendészeti vezetés egyes területein}

„Rendészeti szerveknek nevezzük azokat a közigazgatási szerveket, amelyek rendészeti feladatokat és funkciókat látnak el. Más megközelítés alapján a rendvédelmi szervezetek a rendészeti szervek közül azok, amelyek felhatalmazással rendelkeznek a »legitim erőszak alkalmazására«."12 A klasszikus felfogás szerint a rendészeti szervekben a vezetési folyamatok és funkciók többnyire előszabályzott rendben valósulnak meg. A rendészeti vezetésnek specifikus jellege van, amely rendelkezik az alábbi sajátosságokkal: egyszemélyi parancsnoki rendszer, alá-fölérendeltségi viszony, egyes rendészeti tevékenységek végrehajtása magas fokú tervezettséget és több szerv egyidejű koordinációját igényli. A magyar rendvédelmi szervekről elmondható, hogy alapvetően centralizált vezetési modell a jellemző, amelyben a döntési hatás- és illetékességi körök központosítva jelennek meg. A hierarchikus berendezkedésből adódóan az információáramlás föntről lefelé valósul meg. Az irányítás és a vezetés a fenti szintekről érkező utasításokban, parancsokban valósul meg. ${ }^{13}$ A rendészeti szervekre jellemző egyfajta kettőség, hiszen közigazgatási feladatokat lát el, ahol szolgáltató tevékenységet végez (például igazgatásrendészet), azonban emellett rendelkezik a legitim erőszak monopóliumával, és felel a közrend, közbiztonság fenntartásáért is. A magyar rendészeti szervek bürokratikus szervezetek, azok összes előnyével és hátrányával.

Úgy gondolom, hogy bizonyos szolgálati ágak és feladatok (például igazgatásrendészet, bűnügyi szolgálati ágon belül bizonyos klasszikus feladatok, szervezetirányításhoz kapcsolódó egyéb tevékenységek - gazdasági terület, humán szolgálat stb.) esetében megfelelő a bürokratikus, komplikált környezetre kifejlődött szervezeti forma. Ezekben az esetekben a rendvédelmi szerv szolgáltatói tevékenységet végez, amelyhez ideális ez a vezetési rendszer. Azonban véleményem szerint az előző fejezetben bemutatott dinamikusan változó környezetben más típusú vezetési rendszerekre, vezetői hozzáállásra van szükség a hatékonyság növelése érdekében. A katonai gondolkodásban nemzetközi viszonylatban megjelentek bizonyos új vezetési módszerek, szervezeti formák, vezetési stílusok. Egyes katonai vezetők rájöttek, hogy a tradicionális módszerek és szervezeti struktúrák hatástalanok a komplex műveleti környezetben, különös tekintettel, ha aszimmetrikus vagy esetleg hibrid

\footnotetext{
12 Kovács Gábor: A rendészeti szervekben lejátszódó vezetési folyamatok. Budapest, Dialóg Campus, 2018. 27.

13 Kovács (2018): i. m. 37.
} 
hadviselést folytató ellenséggel kerültek szembe. Ilyen kontextusban értékelődtek fel és kerültek ismét előtérbe az olyan vezetési felfogások, mint a Küldetés Alapú Vezetés $^{14}$ (Mission Command), a Küldetés Alapú Vezetés 2.0, ${ }^{15}$ a civil szférában is alkalmazott Integrált Portfólió Stratégia, ${ }^{16}$ a Csapatok Csapata ${ }^{17}$ felfogás, amely az együttmúködés leghatékonyabb módját írja le, dinamikusan változó környezetben. ${ }^{18}$ Ezeknek az elméleti megközelítéseknek részletes bemutatására tartalmi okok miatt nincs lehetőség, azonban az elméletekhez kapcsolódó egyes elemeket, illetve alapelveket vázolom, mivel úgy gondolom, hogy azok rendészeti területen való alkalmazása növelheti a szervezeti hatékonyságot. Ismételten fontos hangsúlyozni, hogy ezek a vezetési elvek nem a rendészeti szervek egészére alkalmazandók, hanem csak egyes (fentebb már ismertetett) szolgálati ágakra és feladatokra.

A dinamikus környezetben történő hatékony vezetésnek vannak a szervezethez kötött, valamint egyénhez (a vezetőhöz) kötött elemei. Először a szervezet szempontjából releváns elemeket ismertetem:

Decentralizáció - Kiszámíthatatlan környezetben, ahol az egyes döntéseket valószínűleg nem megfelelő és kevés információ hiányában szükséges meghozni, az azok meghozatalára jogosult személyek a szervezeti hierarchiában minél közelebb legyenek a végrehajtó állományhoz. Ennek érdekében fontos a döntési jogköröket alacsonyabb szintű vezetők számára delegálni, továbbá hatásköri és illetékességi szempontból decentralizálni az adott szervezetet, szervezeti elemet. Az ilyen jellegú vezetői felhatalmazás önálló és kezdeményező típusú vezetőket feltételez, nemcsak a szervezet csúcsán, de az alacsonyabb szinteken is. Jól szemlélteti ezt az alapelvet, Charles Krulak amerikai tengerészgyalogos tábornokhoz kötődő Stratégia Tizedes, vagy más néven a "három sarok háborúja” (three block war) elmélete is. ${ }^{19}$ A stratégiai tizedes a decentralizált szervezeti modell jeles képviselője. A katonai hierarchia alacsony szintjén elhelyezkedő végrehajtó, aki tisztában van azzal, hogy az általa meghozott döntések akár stratégiai szinten is kifejthetik hatásukat, így jelentősen befolyásolva a háború végkifejletét. A Krulak tábornok által kidolgozott alapelveket elkezdték alkalmazni a tengerészgyalogos-kiképzés során, és olyan katonákat állítottak szolgálatba, akik önállóan gondolkodó, kezdeményező beállítottságú, döntésképes, szakmailag magasan képzett hivatásosokként kerültek a harctérre.

Képességfejlesztés - A dinamikus környezetre optimalizált szervezetet nem lehet a semmiből, rövid idő alatt megteremteni. Ebből kifolyólag már a válságok, a második fejezetben bemutatott biztonsági kihívások kialakulása előtt szükséges a szervezetfejlesztési stratégiák kidolgozása, a meglévő képességek folyamatos felülvizsgálata, a hiányzó képességek kifejlesztése, megszerzése. Ez a proaktív felfogás alapja

14 Czeglédi Mihály: A küldetésorientált vezetés tartalma. Hadtudományi Szemle, 8. (2015), 2. 68.

15 Porkoláb Imre: Küldetés alapú vezetés a digitális transzformáció korában. In Lóderer Balázs - Stohl Róbert (szerk.): Fegyver nélküli műveletek és háttértényezôik. Budapest, Honvéd Tudományos Kutatómühely, 2019a. 144.

16 Porkoláb (2019b): i. m. 153.

17 McChrystal (2016): i. m.

18 McChrystal (2016): i. m. 261.

19 Charles C. Krulak: The Strategic Corporal: Leadership in the Three Block War. Marines Magazine, January 1999. 
a szervezeti innovációnak, amely szoros összhangban kell, hogy legyen az adaptációval.

Emberközpontúság - Akár katonai, akár rendészeti, akár civil szervezetről beszélünk, a szervezeti célokat a „végrehajtó állomány” éri el. Az egyre hangsúlyosabb technológiai fejlődés háttérbe szoríthatja az emberi dimenziót, de talán az még fontosabb, mint eddig bármikor. Véleményem szerint a szervezeti hatékonyság jelentősen növelhető, ha megteremtjük azokat az objektív (például illetmény, munkakörülmények, technikai feltételek) és szubjektív (például vezetői hozzáállás, morál, tolerancia) feltételeket a munkát végzők számára, amelyek összhangban vannak az egyének elképzeléseivel, céljaival.

Minőség a mennyiség előtt - A biztonsági környezetből adódó kihívások kezeléséhez magasan képzett, kezdeményező, önálló egyénekre van szükség a rendészeti szervek állományában. E képességek megszerzése idő- és pénzigényes, továbbá nagyban befolyásolja a kiválasztási rendszer is az állomány összetételét. Úgy gondolom, hogy ezeket a tényezőket figyelembe véve, célszerủbb olyan egyéneket képezni, akik egy jól átgondolt, a feladathoz alkalmazkodó (fizikai, egészségügyi, mentális) szelekciót követően, egy alapos, valós és használható tudást nyújtó kiképzésen mennek keresztül. A költségesen és időigényesen kiképzett állomány megtartása ugyancsak kulcsfontosságú, amely szorosan kapcsolódik az emberközpontúság alapelvéhez.

Helyzettudatosság - A John Boyd amerikai repülőezredes által kifejlesztett döntéshozatali mechanizmus, az úgynevezett OODA-Loop (OODA-hurok) ${ }^{20}$ mind szervezetek, mind egyének számára sikeres érvényesülést tesz lehetővé dinamikusan változó környezetben. Az elmélet szerint a döntéshozó megfigyeli (observe), majd értékeli (orient) saját helyzetét, majd erre alapozva gyors döntést (decide) hoz, és megvalósítja azt (act). Ezt követően az új döntési helyzetben a folyamat újraindul (loop). A módszer nem foglalkozik a bizonytalansági tényezővel vagy az információhiánnyal, amely a dinamikusan változó, VUCA-környezet sajátja, hanem a rendelkezésre álló információk, a mindig aktuális helyzet alapján születik meg a vezetői döntés. Az elmélet mind szervezeti (stratégiai döntéshozatal), mind egyéni szinten alkalmazható a kiszámíthatatlan helyzetekben a gyors, hatékony döntések meghozatalához. ${ }^{21}$

Szervezeti adaptációs képesség, szervezeti tanulás - A 21. században elérkeztünk egy olyan állapotba, ahol az emberi és ezáltal a szervezeti alkalmazkodóképesség nem képes lépést tartani a technológiai változásokkal. Az informatika, robotika, a mesterséges intelligencia területén exponenciális a növekedés. Az új környezethez, új technológiai folyamatokhoz való adaptálódásunk jóval lassabb, mint magának a technológiának a megújulása. Ebből kifolyólag a szervezeti adaptáció során új képességeket kell a középpontba állítanunk. A technológiai újítások helyett a tanulási képességek fejlesztésére, a problémamegoldásra, a kritikus, önálló gondolkodás erő-

\footnotetext{
20 Observe - megfigyelés, orient - tudatosítás, orientálódás, decide - döntés, act - cselekvés, loop - hurok.

21 Porkoláb (2019b): i. m. 93.
} 
sítésére, a kreativitásra, a kommunikációra, a kooperációra, illetve a változó környezethez való gyors alkalmazkodásra érdemes helyeznünk a hangsúlyt.

Együttműködés - Véleményem szerint a dinamikus környezetben való érvényesülés egyik sarokköve. A mai, interdependenciával átszőtt világban a szervezetek (hivatásrendek) közötti együttműködés kritikus jelentőségű. Fel kell ismerni azt a tényt, hogy egyedül nem vagyunk képesek sikereket elérni, azonban a valódi bizalomra, a közös célba vetett hitre épülő tényleges együttmúködéssel megvalósítható a hatékony fellépés.

A dinamikusan változó környezetben megvalósított vezetés másik fontos eleme („az érem másik fele”) az egyéni szinten, tehát a vezető által alkalmazott alapelvek.

Bizalom - A csoport tagjait - legyen az akár végrehajtók csoportja vagy akár középvezetők csoportja - a kölcsönös bizalom és a közös céltudat ruházza fel a problémamegoldás leghatékonyabb képességével. A vezető és a csapattagok között meglévő feltétlen bizalom lesz az, amelyre a változó környezetben végzett munka épülni fog. A parancsnoknak a kívánt végállapotot (célt) kell meghatároznia, a végrehajtás teljes mértékben az állományon múlik. A „mikromenedzselés” (a részfeladatok folyamatos irányítása) nem kívánatos. Ahhoz, hogy ez a bizalom múködjön, vannak bizonyos előfeltételek. Először is a vezetőnek és a csoport tagjainak osztoznia kell a közös célba vetett hitben - továbbá annak egységes értelmezésén -, azaz, hogy a feladat, amelyet el kell végezniük, értelmes, végrehajtható és mindenki által támogatott. Másodszor magas szintű kreativitásra és önálló, kritikus gondolkodásra nevelő kiképzésben, továbbképzésben, oktatásban osztoznak a csoport tagjai, mindemellett a csoportkohézió magas fokú.

A vezetô is csak a szervezet része - Nagyon fontos felismerés, hogy a vezető sem rendelkezik fontosabb pozícióval a csoporton belül, mint annak a többi tagja. Ô is csak a „gépezet része”, neki is megvan a maga funkciója, de ez egyáltalán nem különb a szervezet (csoport) egyéb funkciójától. Úgy gondolom, hogy általánosságban ezt a legnehezebb elfogadni, felismerni a legtöbb vezetőnek.

Kreativitás - Egyes problémák, feladatok megközelítése nagyfokú kreativitást, valamint a megszokottól (a „sémától”) való eltérő gondolkodást igényel, különösen dinamikusan változó környezetben. A vezető felelőssége, hogy teret enged a csapattagok, illetve a saját kreativitásának. Egyes amerikai rendészeti szervezetek (mint például az FBI HRT - Federal Bureau of Investigation Hostage Rescue Team - Szövetségi Nyomozó Iroda Túszmentő Csoport egysége) egy-egy válság alkalmával előszeretettel vonnak be teljesen civil (semmilyen rendészeti jártassággal, képzettséggel nem rendelkező) állampolgárokat a vezetési pontok/válságkezelő központok munkájába. Teszik mindezt azért, hogy meghallgassák olyan emberek véleményét, akiknek nincs semmilyen prekoncepciója vagy előzetes tudása ilyen szituációk kezeléséről, így lehetséges, hogy egy olyan megoldást tudnak bevinni a csoport munkájába, amelyre a szakemberek nem gondolnak. Ez az a tipikus kereteken kívüli gondolkodásmód (thinking outside the box), amely segítséget nyújthat dinamikusan változó viszonyok között. 
Egyéni tanulási képesség - Mint ahogy szervezeti szinten is érvényes a technológiai fejlődés exponenciális változása, úgy érezhető annak hatása az egyén szintjén is. A jó vezetőnek nem új technikai képességekre, új ismeretanyagra van szüksége, hanem új tanulási képességekre, amely bármikor kamatoztatható a gyorsan változó helyzetekben, ezáltal segítve a döntéshozatalt, akár információ- és időhiányos környezetben is.

Extrém felelösségvállalás - A VUCA-környezetben tevékenykedő vezetőnek extrém felelősségvállalással kell rendelkezni. A parancsnoknak (csoportparancsnok, középvezető stb.) minden a csoportja tagjai által elkövetett hibáért ő tartozik felelősséggel. Amennyiben hibázik a csoport, a vezető volt az, aki nem készítette fel őket megfelelően a feladat végrehajtására, nem teremtette meg a megfelelő feltételeket (technikai, anyagi stb.) vagy adott esetben ő nem mondta azt egy adott feladatra, hogy ezt a csoport nem képes elvégezni, tehát rosszul mérte fel a helyzetét. A siker a csoport közös érdeme, a kudarc a vezető felelőssége. ${ }^{22}$

Szolgáló típusú vezetés - A 2000-es években egyre fontosabb lett a szolgáló vezetés koncepciója, amelynek lényege, hogy a vezető kötelessége követői érdekeinek képviselete. Egy szolgáló vezető mindig igyekszik feltérképezni, hogy mire van szüksége a csoportja tagjainak. Nem az egyéni érdekeiket, hanem a feladat elvégzéséhez szükséges erőforrások megszerzését tartja relevanciában. A szolgáló vezető sem engedi szabadjára a beosztottjait, ugyanúgy követelményeket támaszt, azokat viszont annak érdekében teszi, hogy a maximális teljesítményt érhessék el a végrehajtók. ${ }^{23}$

Kertész típusú vezetés - A Stanley McChrystal tábornok által bevezetett koncepció lényege, hogy a jó vezetőnek olyannak kell lennie, mint egy kertésznek. A kertész a növényei fejlődéséhez megteremti a feltételeket, gondozza a talajt, vegyszerezi, öntözi őket, de a munkát (a fejlődést) nem végzi el helyettük. A vezetőnek is meg kell teremtenie a feltételeket, erőforrásokat, eszközöket ahhoz, hogy a beosztottak a képességeikhez mérten a lehető legjobban el tudják végezni a rájuk bízott feladatokat. A parancsnoknak ellen kell állnia a kísértésnek, hogy sakkmester módjára akarjon minden lépést irányítani, és teret kell engedni a kertész vezetői felfogásnak, tehát a közvetlen irányítás (mikromenedzselés) helyett a felhatalmazás, illetve a feltételek biztosítása kell, hogy legyen a középpontban. Azonban a kertész típusú vezető nem lehet passzív, a szervezeten, amelyben a vezetői tevékenység megvalósul, folyamatosan rajta tartja a szemét, de ezt „Tartsd nyitva a szemed, de el a kezekkel” elv alapján teszi. ${ }^{24}$

Komplex adaptív vezetés - A jó, dinamikus környezetben vezető egyénnek el kell sajátítania a komplex adaptív vezetés képességét, amely az embert helyezi a szervezet, a vezetés fókuszába. A csoport (szervezet) tagjai tisztában vannak a szervezeti célkitűzésekkel, megvan a bizalom a tagok között és ezek figyelembevételével - a vezetői

\footnotetext{
22 Jocko Willink - Leif Babin: Extreme ownership: How U.S. Navy seals lead and win. New York, St. Martins Press, $2^{\text {nd }}$ edition 2017.

23 Porkoláb (2019b): i. m. 184-185.

24 McChrystal (2016): i. m. 301.
} 
felhatalmazás birtokában - önállóan cselekszenek, alapozva a közös tudásra, amelyet a felkészítés és a művelet során folyamatosan frissítenek. ${ }^{25}$

\section{Következtetések, javaslatok}

A dinamikusan változó környezetben történő rendészeti vezetéssel kapcsolatban következtetéseim az alábbiak:

- Az elmúlt 20 évben (2001. szeptember 11-ét követően) a világ gyökeresen megváltozott. Megjelentek olyan új kihívások (narkoterrorizmus, aszimmetrikus hadviselés, hibrid hadviselés), illetve felerősödtek olyan régi fenyegetések (nemzetközi, új típusú terrorizmus, migráció), amelyek jelentősen befolyásolták a biztonsági környezet változását. Ezt a folyamatot erősítette az a tény, hogy az interdependencia egyre hangsúlyosabbá vált, amelynek következtében a környezet egyre kiszámíthatatlanabb, bizonytalanabb lett. A változás egyik hatása volt, hogy a rendészeti és a honvédelmi hivatásrend elkezdett közeledni egymáshoz, ami ma is több területen megfigyelhető. Ezen jelenségek egyik oka lehet, hogy a fenyegetések ma már nem választhatók tisztán szét belbiztonsági, illetve külső fenyegetésekre, valamint előkerültek olyan elemek is, amelyek korábban nem léteztek és nehezen meghatározható, hogy mely területhez tartoznak (például kiberbűnözés - kiberhadviselés).

- A biztonsági környezet elemzése során négyfajta típust tudunk beazonosítani: egyszerű, bonyolult (komplikált), dinamikusan változó (VUCA), kaotikus. A legtöbb tradicionális államigazgatási, bürokratikus szervezet a bonyolult környezetben való múködésre jött létre, azonban az új kihívások VUCA-környezetet eredményeznek, ahol a kiszámíthatatlanság, az idő- és információhiány, a bizonytalanság állandó jellemzők. Az ilyen környezetben operáló szervezetek (csoportok) hatékony vezetéséhez új típusú vezetési elveket, elméleteket érdemes alkalmazni.

- A rendészeti szervek bizonyos szolgálati ágai és feladatai nem igényelnek a tradicionálistól eltérő vezetési módszereket, ezek főleg a szolgáltató jellegű tevékenységek. Azonban vannak olyan feladatok és azok végrehajtására rendelt szervezetek, amelyeknek célszerű elsajátítani a dinamikusan változó viszonyok közötti vezetés alapelveit.

- A VUCA-környezetben történő vezetésnek vannak a szervezetre, valamint az egyénre (a vezetőre) vonatkozó elvei, amelyeket érdemes szem előtt tartani az eredményes alkalmazás érdekében.

Porkoláb (2019b): i. m. 106. 


\section{FELHASZNÁLT IRODALOM}

Bezerédi Imre: Biztos út..., avagy gondolatok az egyes rendészeti feladatot ellátók tevékenységéről. Hadtudományi Szemle, 13. (2020), 1. 147-157. Online: https://doi.org/10.32563/ hsz.2020.1.11

Boldizsár Gábor: Paratroopers in future operations. Security and Defence Quarterly, 3. (2014), 2. 46-60. Online: https://doi.org/10.5604/23008741.1152569

Czeglédi Mihály: A küldetésorientált vezetés tartalma. Hadtudományi Szemle, 8. (2015), 2. 68-79. Online: http://epa.oszk.hu/02400/02463/00027/pdf/EPA02463_hadtudomanyi_szemle_ 2015_02_068-079.pdf

Kovács Gábor: A rendészeti szervekben lejátszódó vezetési folyamatok. Budapest, Dialóg Campus, 2018.

McChrystal, Stanley: Csapatok csapata - Szervezeti együttműködés és elköteleződés felsőfokon. Budapest, HVG, 2016.

Porkoláb Imre: Küldetés alapú vezetés a digitális transzformáció korában. In Lóderer Balázs - Stohl Róbert (szerk.): Fegyver nélküli müveletek és háttértényezőik. Budapest, Honvéd Tudományos Kutatómühely, 2019a. 141-157.

Porkoláb Imre: A stratégia müvészete - Szervezeti innováció kiszámíthatatlan környezetben - Szun-Ce gondolatai alapján. Budapest, HVG, 2019b.

Willink, Jocko - Leif Babin: Extreme ownership: How U.S. Navy seals lead and win. New York, St. Martins Press, $2^{\text {nd }}$ edition 2017.

\section{Jogi forrás}

1163/2020. (IV. 21.) Korm. határozat Magyarország Nemzeti Biztonsági Stratégiájáról

\section{Internetes források}

Krulak, Charles C.: The Strategic corporal: Leadership in the Three Block War. Marines Magazine, January 1999. Online: https://doi.org/10.21236/ADA399413

Országgyülés Hivatala: A különleges jogrend és a veszélyhelyzet. Infojegyzet, (2020), 6. 1-4. Online: www.parlament.hu/documents/10181/4464848/Infojegyzet_2020_6_kulonleges_jogrend+\%281\%29.pdf/f7c3e7e1-9b7d-cb32-3bf2-174e8d25b56c?t=1585507104211

Trautmann Balázs: Európa veszélyben? honvedelem.hu, 2015. 12. 15. Online: https://honvedelem. hu/hatter/biztonsagpolitika/europa-veszelyben.html

\section{ABSTRACT}

\section{Law Enforcement Leadership in a Dynamically Changing Environment}

Dávid BERTALAN

The central theme of the study is how the security environment has changed over the past 20 years since the September 11, 2001 terrorist attacks in New York. It also discusses the phenomena and threats that have shaped both the domestic and international security environment, and how our world has become increasingly unpredictable, uncertain, and 
how the dynamically changing environment has evolved. I present the phenomenon of the convergence of law enforcement and the military. In the second part of the study, I present theories applicable to some law enforcement organisations, new types of management theory methods, and related principles that can help in the management of an organisation under dynamically changing conditions.

Keywords: dynamically changing environment, VUCA, law enforcement leadership, convergence of military and law enforcement, mission command 